\title{
Bacteriological Finding
}

National Cancer Institute

\section{Source}

National Cancer Institute. Bacteriological Finding. NCI Thesaurus. Code C102602.

Objective evidence of bacterial infection perceptible to the examiner by laboratory procedure. 